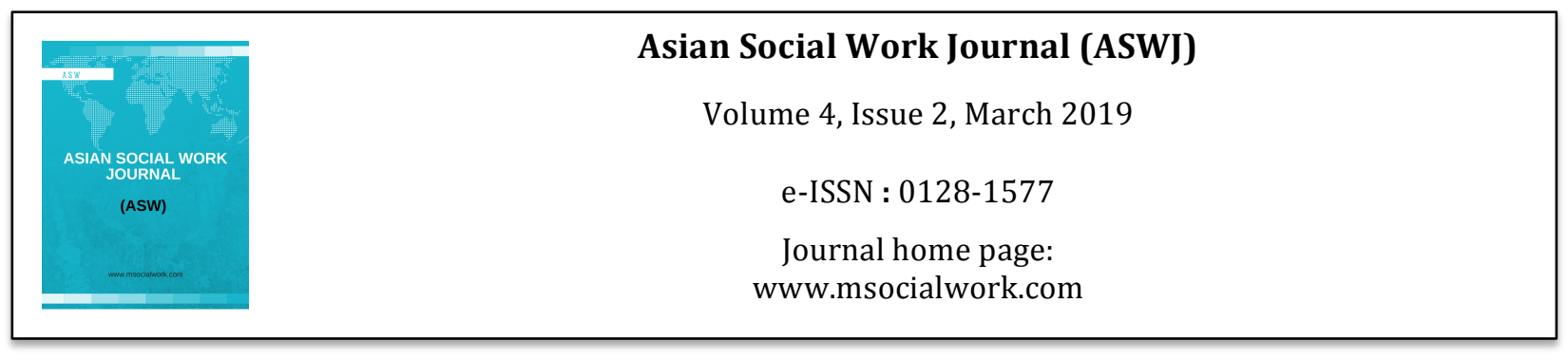

\title{
The Infection Control Risk Assessment and Strategies to Reduce HAIs at Hospital in Yogyakarta Indonesia
}

\author{
Elsye Maria Rosa ${ }^{1}$, Ekorini Listiowati ${ }^{1}$, Nurmalita Sari ${ }^{1}$ \\ 1Department of Hospital Management, Universitas Muhammadiyah Yogyakarta \\ Corrrespondence: Elsye Maria Rosa (elsye@umy.ac.id)
}

\begin{abstract}
Identifying the problem of infection is needed to analyze risk management. One of the tools to manage the risk of Hospital-Acquired Infections (HAIs) is by using the ICRA (Infection Control Risk Assessment). Arranging a risk assessment of infection control is essential to prevent the potential incidence of infection that is not expected. This research analyzes the Infection Control Risk Assessment and reduction strategies of Health-Care-Associated Infections at Hospital in Yogyakarta . The type of analysis was descriptive qualitative with case study approach. The researcher used informants who were involved in the implementation of the prevention and infection with the data control. The researcher also collected data using depth interviews and documents reviews. Risk management process, the findings of risk identification (1) the transmission of infectious diseases, microorganisms through direct and indirect contact, (2) infection, (3) the duration of treatment, delayed homecoming, disability, (4) healthcare workers, patients, visitors, and hospital environments. The highest risk assessment was surgical site infection. The HAIs reduction strategies were taken by breaking the chain of infection, bacterial identifying using HAIs, using the rational antibiotic, optimizing surveillance of HAIs, implementing periodic regular meetings, reporting, cooperating, evaluating, socializing, monitoring and preventing, the reinvigorating the SOP for the type of HAIs. The advice for the management of Hospital is that they need to notice more on the implementation process of the prevention and infection control.
\end{abstract}

Key words: hospital acquired infections, infection control risk assessment

\section{Introduction}

HAIs (Hospital-Acquired Infections) is known as nosocomial infections or also known as hospital infection which is the most common complication in the health service. Infection is the most common effect found in the hospital that affects approximately 5 to $10 \%$ of hospitalized patients in developed countries, and a significant burden on the states whose background was lower ${ }^{1}$. The impacts caused by nosocomial infections (HAIs) are many, as examples, they can pose a risk of exposure to infection which is not only experienced by the patient but also for the health care workers, family, and visitors ${ }^{2}$. According to Weston, HAIs also give impacts on the patient and the family which can cause financial loss, harm, disability or death, increased the length of stay, extra expenses for hospitals and can degrade the image of the hospital ${ }^{3}$. Risk management is fundamental to prevent and reduce the dangers arising from the Health-care Associated Infections (National Health and Medical Research Council, 2010). According to Clough and Sears (1994 cited in ISO 3001 in 2009), risk management is defined as a comprehensive approach to address all of the events that cause lost. The need for risk management 
in the hospital is in anticipation of adverse events which can occur at any time ${ }^{4}$. Based on the Indonesian Ministry of Health (2010), in the hospital accreditation standards of PPI 10.6 that infection prevention and control processes were designed to reduce the risk of infection for patients, staff, and others. Hospitals should be proactive in identifying and following the path of danger, numbers, and the tendency of hospital infection ${ }^{5}$.

In Aisyah \& Satyabakti, it is mentioned that in Indonesia, based on the results of research conducted in 11 hospitals in Jakarta in 2004 that there was 9.8 percent of hospitalized patients were infected while undergoing treatment ${ }^{6}$. A study by Daniati (2009, in Aisha \& Satyabakti 2013) showed that the results data of HAIs in RSUD Semarang in 2009 were 131 cases of phlebitis, 38 cases of infection in the surgery area, 23 cases of Urinary Tract Infection (UTI), 22 cases of sepsis, 7 cases of pneumonia and 6 cases of decubitus. The result report of PPIRS committee year 2015 at RS PKU Muhammadiyah Yogyakarta about HAIs were the data of phlebitis infection was 8.7 per mile, no case of infections caused by the installation of central venous, $0 \%$ of VAP, and $3.74 \%$ of IDO data which was still unknown $^{6}$.

Indonesian Department of Health in 2009 declared that the number of HAIs cases become one measure of hospital accreditation in Indonesia ${ }^{6}$. Then the number of cases of nosocomial infections is also used as an indicator of a hospital's quality of service. The quality of hospital care services can be assessed by the level of utilization of services by the community, quality of service and level of hospital efficiency. One indicator of success in the service of the hospital is the low rate of nosocomial infections (HAIs) in the hospital. The standard in hospital accreditation system version of 2012 emphasizes on the security and safety of the patient and to avoid contamination during hospitalized ${ }^{7}$.

ICRA is an infection control process planning, whose main subject in the setting of its basic program and development, based on the continuity of surveillance and implement regulatory changes if there are changing challenges in the field. Lardo, et al (2016) outlines that ICRA (Infection Control Risk Assessment) is an essential complement in planning, development, monitoring, evaluation, and efforts to make the consideration of the various stages and levels of risk of infection, which are VAP (Ventilator-Associated Pneumonia), BSI (Primary Blood Stream Infection), Catheter-Associated Urinary Tract Infection (CAUTI), and SSI (Surgical Site Infections) in each service area.

\section{Methodology}

This type of research used in this study was qualitative research with case study design. The participants of the survey covered the hospital management, the Committee of PPIRS team, and the workers in the inpatient unit. This study used informants who were considered competent in providing information from the hospital that was the team leader of PPIRS (Prevention and Control of Hospital Infection), IPCN (Infection Preventive Control Nursing), the head of the inpatient rooms, and IPCLN (Infection Preventive Control Link Nursing), inpatient workers involved in the implementation of infection prevention and control. In this study, the sampling technique in determining the sample or informants used purposive sampling technique.

The instruments used in this study were Infection Control Risk Assessment, interview guidelines adapted to the needs of research, and documents review.

\section{Result}

The implementation of the management of the risk of infection in infection prevention and control program at Hospital 
Table 1.1: The application of risk management in the prevention and control program of hospital infections

\begin{tabular}{ll}
$\begin{array}{c}\text { The overview of } \\
\text { infection risk } \\
\text { management } \\
\text { system }\end{array}$ & \multicolumn{1}{c}{ The process of infection risk management } \\
system
\end{tabular}

The participation of the workers

Communication and information

The influence of leaders

HAIs risk awareness culture
Involvement of workers:

1. Participating based on the standards action operational procedure

The role of head of the rooms, IPCN, IPCLN:

2. Supervising, monitoring, and giving a warning related to the use of APD, the implementation of hand washing, the application of the five moments

3. Reporting the surveillance activities through SIM

The dissemination of information:

1. Interface and data could be easily accessed through computers in each group

2. The latest news could be obtained through discussion, conference meetings, training, reporting, poster/leaflet media

3. IPCLN passed the information to each task unit

The roles of the leaders:

1. Had a great contribution

2. Leaders strongly supported the Infection Control program

The missing roles of the leaders:

1. Lack of a direct part of leader

2. There was no evaluation or feedback for improvement

3. There was no reward-punishment

Risk awareness culture:

All of them were already aware of the risk of infection

\section{The evaluation of infection risk management system process}

PPI's program has not run optimally yet, but there is support from management already.
There were involvement and participation of health workers in the implementation of decreasing HAIs in unit

The transfer of data from Infection Control to health workers in the group was easier

There was full support, from the proactive leader in the implementation of Infection Control.
Infection risk awareness culture already existed but the behavior of risk awareness was still not 
Activities that can reduce and prevent infection:

1. Washing hands

2. Using PPE

Behavioral risk awareness culture:

1. The implementation of PPE was sometimes still not appropriate

2. The compliance with hand washing was still not optimal

3. Sometimes they forgot the six steps of hand washing and skip the execution of five moments

The obstacles to the implementation

Cooperation

The expectations of the workers
The barriers to the program implementation:

1. The completeness procurement of infrastructure in unit

2. The difficulties of implementing prevention such as forget to wash hands, forget of 5 moments

3. The problems in changing habits

4. Inadequate resources

5. Every worker had unique characteristics

\section{Cooperation between Infection Control teams} to each unit:

1. It was going pretty well, the communication was good

2. The implementation of collaboration is still felt less maximum in the Operating room

The cooperation between the Operating Room and CSSD has a problem in the CSSD human resources.

The hopes for change, support, and improvement:

1. Improving the compliance with hand washing

2. Behaving well to keep HAIs

3. There is supervision, routine and periodic evaluation

4. There is reward-punishment

5. There is feedback

6. The professional attitude, the attitude improvements of the individual based on the standards optimal.

The obstacles came from the inadequate human resources and difficult to change habits.

The implementation of cooperation is still less than the maximum in inpatient, outpatient and Operating Room

Proactive support from the workers

\section{HAIs Risk Identifications}

Table 1.2 Identification of risk in HAIs Risk Management

\begin{tabular}{lll}
\hline \multicolumn{1}{c}{ Risks } & \multicolumn{1}{c}{ Possible Causes } \\
\hline 1. & $\begin{array}{l}\text { Transmission of infectious diseases through } \\
\text { skin contact }\end{array}$ & Hygiene of individual worker, patients, or visitors \\
2. $\begin{array}{l}\text { The transfer of germs such as bacteria, } \\
\text { viruses, fungi/parasites }\end{array}$ & \\
\hline
\end{tabular}




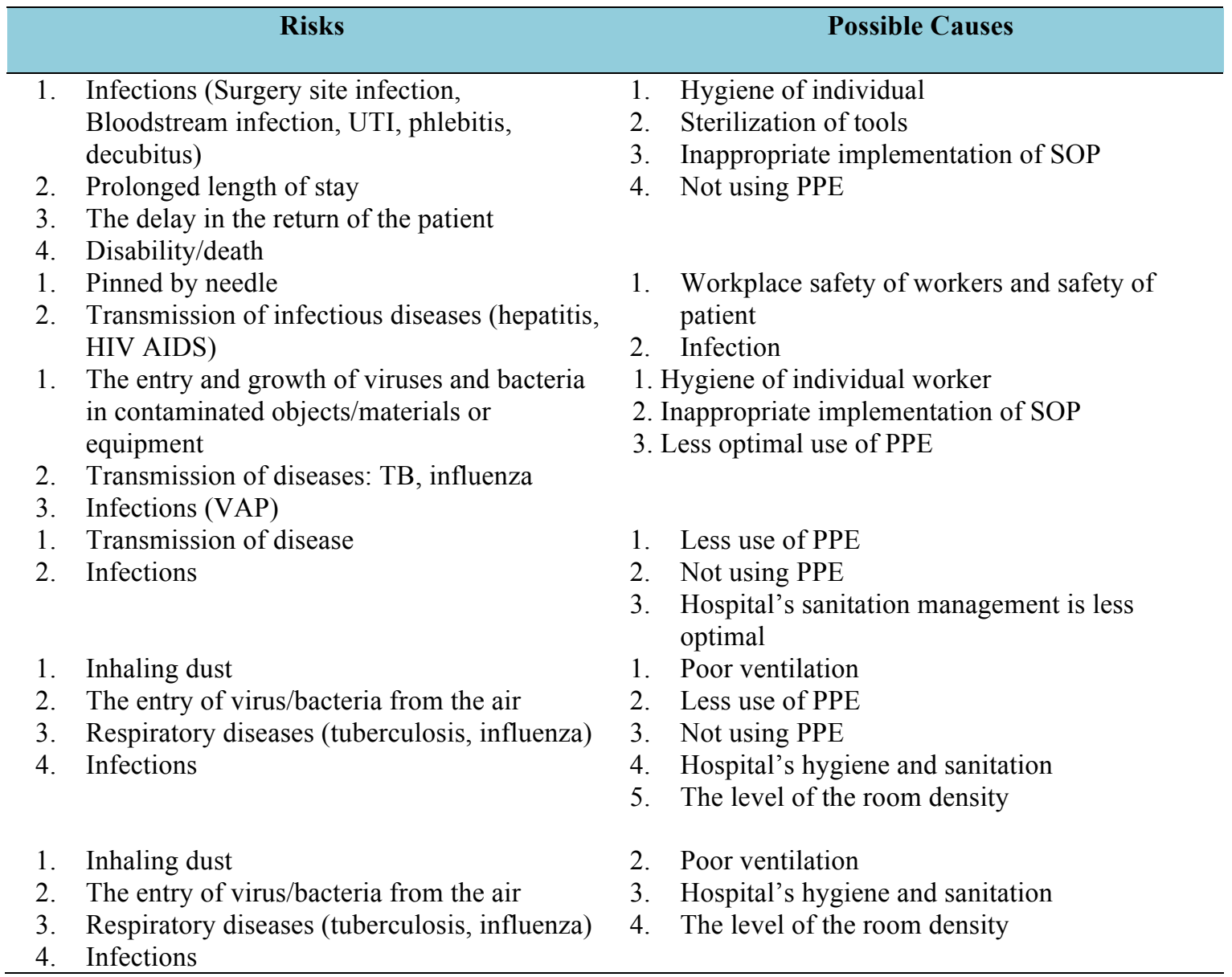

\section{HAIs Risk Analysis}

Table 1.3 HAIs Risk Analysis

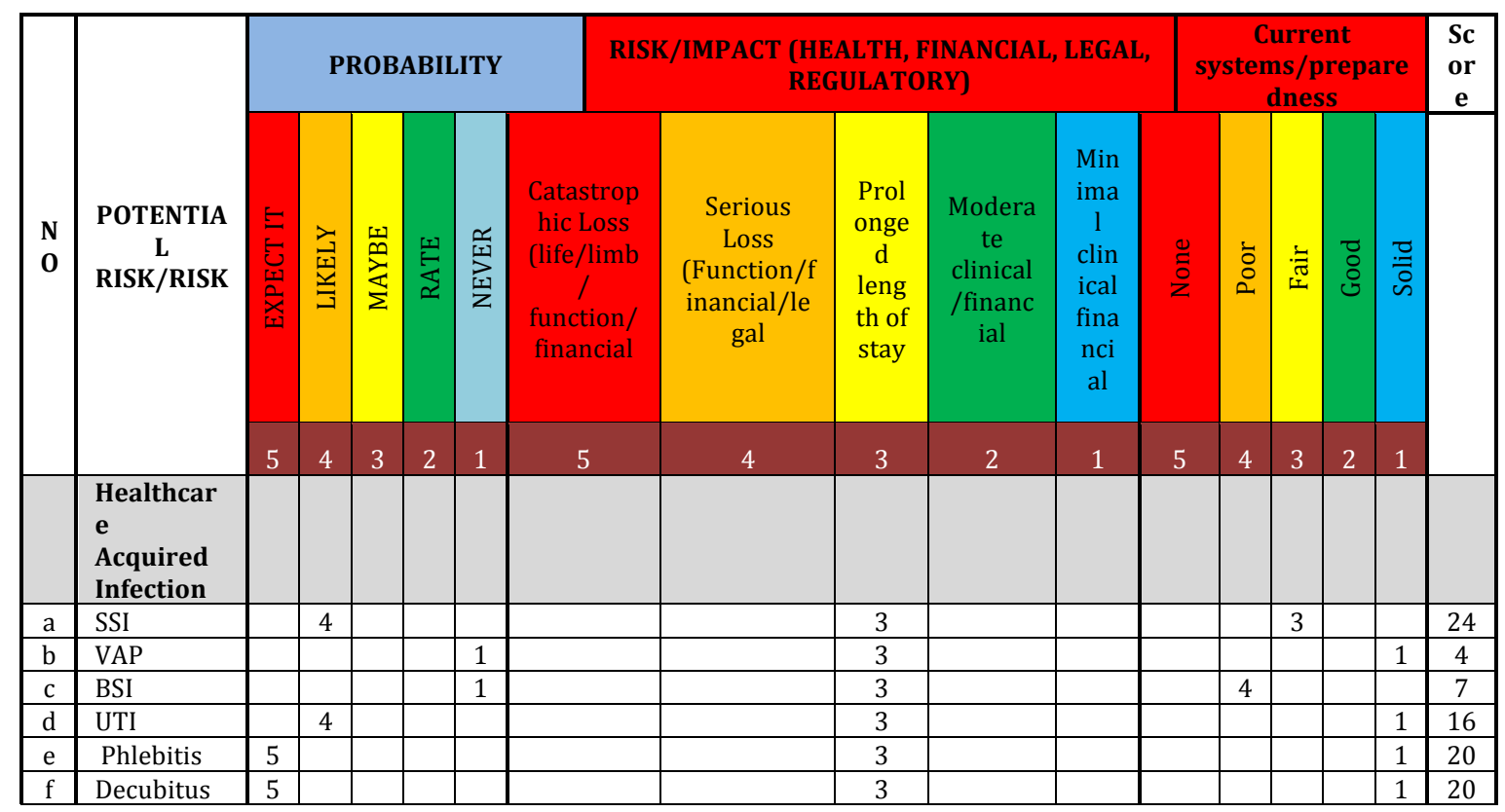


Table 1.4: HAIs Priority Risk at Hospital

\begin{tabular}{ll}
\hline HAIs potential risks & Score \\
\hline SSI & 24 \\
Phlebitis & 20 \\
Decubitus & 20 \\
UTI & 16 \\
BSI & 7 \\
VAP & 4 \\
\hline
\end{tabular}

The table shows the priority that the potential risks with the highest score are Surgical Site Infections.

\section{HAIs Risk Assessment}

The results of this phase are the stage to assess the analysis of the HAIs risks by comparing the probability and impact of the risk analysis.

Table 1.5 Risk assessment matrix

\begin{tabular}{|c|c|c|c|c|c|}
\hline \multirow[t]{2}{*}{ Possibility } & \multicolumn{5}{|c|}{ Impact } \\
\hline & $\begin{array}{c}\text { Insignificant } \\
1\end{array}$ & $\begin{array}{c}\text { Minor } \\
2\end{array}$ & $\begin{array}{c}\text { Moderate } \\
3\end{array}$ & $\begin{array}{c}\text { Major } \\
4\end{array}$ & $\begin{array}{c}\text { Catastrophic } \\
5\end{array}$ \\
\hline $\begin{array}{c}\text { Very often } \\
5\end{array}$ & & & $\begin{array}{l}\text { Phlebitis, } \\
\text { decubitus }\end{array}$ & & \\
\hline $\begin{array}{c}\text { Often } \\
4\end{array}$ & & & & SSI & \\
\hline $\begin{array}{c}\text { Sometimes } \\
3\end{array}$ & & & UTI & & \\
\hline $\begin{array}{c}\text { Rarely } \\
2 \\
\end{array}$ & & & & & \\
\hline $\begin{array}{c}\text { Never } \\
1\end{array}$ & VAP & & BSI & & \\
\hline
\end{tabular}

\section{Notes:}

: Low risk

: Moderate risk

: High risk

: Very high risk (extreme) 


\section{Follow-up and SSI Reduction Strategies}

Table 1.6: Follow-up and HAIs Risks Reduction Strategies

\begin{tabular}{|c|c|c|c|c|c|c|c|}
\hline HAIs & Score & Risk level & $\begin{array}{l}\text { General } \\
\text { purpose }\end{array}$ & $\begin{array}{l}\text { Specific } \\
\text { purpose }\end{array}$ & Strategy & Risk evaluation & $\begin{array}{l}\begin{array}{l}\text { Follow-up analysis and } \\
\text { strategy }\end{array} \\
\end{array}$ \\
\hline ID0 & 24 & Very high & $\begin{array}{l}\text { Reducing } \\
\text { the case of } \\
\text { SSI }\end{array}$ & $\begin{array}{l}\text { Decreasing } \\
\text { number of } \\
\text { SSI case }\end{array}$ & $\begin{array}{l}\text { Infection Control Services training, } \\
\text { the provision of hand hygiene } \\
\text { facilities (sink and hand-rub), } \\
\text { educational materials and Infection } \\
\text { Control services leaflets (hand } \\
\text { hygiene), refreshing of pre-surgery } \\
\text { management, during surgery, post- } \\
\text { surgery, refreshment for wound care } \\
\text { management, making SSI } \\
\text { surveillance format and socialization } \\
\text { on how to fill. }\end{array}$ & $\begin{array}{l}\text { Infection Control services } \\
\text { training has been done, workers } \\
\text { compliance on And hygiene is } \\
\text { still lacking, on refreshing for } \\
\text { patients Alt surgery, SSI } \\
\text { surveillance has been created } \\
\text { but has not been socialized. }\end{array}$ & $\begin{array}{l}\text { 1. Audit on SPO of } \\
\text { hand hygiene, } \\
\text { 2. Monitoring of hand } \\
\text { hygiene compliance, } \\
\text { 3. Do refreshing for } \\
\text { patients with } \\
\text { surgery and } \\
\text { 4. Do socialization of } \\
\text { SSI surveillance, } \\
\text { 5. Identify and control } \\
\text { the detailed wound } \\
\text { operation }\end{array}$ \\
\hline
\end{tabular}

Source: Primary data of hospital Infection Control team which has been analysis

\section{Discussion}

Based on the result of interview analysis with the informants, the cooperation among Infection Control team to each unit in decreasing HAIs risks was well conducted, the communication was excellent, yet the implementation of teamwork was not maximum in inpatient, outpatient, and Operating room. They supported the Infection Control program and expected that the application of infection prevention and control would improve hand-hygiene compliance, perform a good behavior to avoid HAIs risks, and conduct regular monitoring and evaluation.

Some of the informants explained that they expected the reward-punishment system also feedback of the prevention and control to improve any implementation deficiencies. Individually, they planned to shape professional attitude and attitude improvement to meet the standard in minimizing infection.

The implementation of the infection control risk program is one of the principal essential activities to prevent and control infection in the hospital. Based on the analysis, it was mentioned that the role of management and staff or medical staff was essential. According to Good of Corporate Governance, risk management is part of managerial responsibilities which is inseparable from the process of organization, project or program and management of development. Risk management is not an independent activity separated from any other organizational means in attaining the goals.

Organizational risk management according to COSO (2004) in Astuti (2010) is a process influenced by the board of directors, management, and other personnel, of which method is involved in developing strategies and is designed to identify any potential events possible to influence the entity and to manage risks which cover risk range and proper protection related to the attainment of its objectives. In this research, the support from management was needed in supporting Infection Control program to implement the process of infection risk management ${ }^{9}$.

\section{HAIs risk identification and analysis}

National Health and Medical Research Council mentioned that the influence of HAIs problems did affect not only the patients but also the workers in the hospital such as health management in any units including office-based activities. This also meant that workers and visitors were susceptible to transmit infections. Potential sources to spread HAIs were health-worker hands, medical tools, and patient body 
fluids. HAIs infection was transmitted through both direct and indirect contact between health worker to patient, a visitor to the patient, and health care area ${ }^{10}$.

The risk from HAIs is the penetration and growth of virus, bacteria or other microorganisms which may cause infections such as SSI, ISK, BSI, VAP, phlebitis, and decubitus. It may also affect the length of cure, delay of hospital homecoming, disability even death, and respiratory disorder. The possibilities of HAIs risk sources described in Table 1.3. are health worker hygiene, tool sterilization, minimum APD use, improper SOP implementation.

The Health Department mentioned that infection risks were low when there was direct contact between organisms and intact skin, and everyday humans touched the surface of stuff where there were organisms. Infection risks increase when there is contact with a mucous membrane or non-intact skin. It grows when microorganisms have direct contact with non-sterile part of the body that enables the exposure of organism which causes disease ${ }^{11}$. After the analysis, infection risks transmission in Hospital had to be cut.

To cut HAIs infection in the hospital, HAIs prevention with self-protection tools and health worker hand-hygiene were implemented. Based on the interview, the respondent mentioned that they were fully aware of keeping the hygiene of their hands by regularly washing them though sometimes they forget to do it. Ernawati et al. (2014) defined hand washing to maintain health was one of the most critical activities to decrease the possibility of microorganism transmission and to prevent infection. If it were well implemented, this activity would be able to avoid microorganism transmission and reduce the number of HAIs ${ }^{12}$.

Hand hygiene is one way to deal with a health problem and an important aspect holistically and the most practical method to save the cost in reducing infection due to the spread of microbes resistant in all health care and health service system. Even though it was a simple action, health workers handhygiene compliance was still low ${ }^{1}$. Some of the health workers mentioned the obstacle in implementing infection prevention and control in inpatient rooms was the health workers who sometimes forgot to wash their hands before performing five moments.

In a further analysis based on the interview result, the health workers had implemented six steps of hand washing and five moments of hand washing to maintain the hygiene, yet they sometimes forgot and were not aware of washing their hands. Based on the analysis of hand washing compliance evaluation, some of the health workers did not receive individual assessment related to the implementation of hand washing. Figure 6 below describes the steps of hand washing and the application of 5 moments based on $\mathrm{WHO}^{13}$.

\section{Risk Assessment}

Based on the risk assessment elaborated in this research, the highest risk of HAIs type was SSI. Mawalla et al. explained that surgical site infection (SSI) had been reported as the most common HAIs that was $20-25 \%$ of HAIs around the world. SSI was responsible for the increase in cost, morbidity, and mortality related to surgery and remained as the biggest issue in the world. SSI level was reported from averagely $2.5 \%$ to $41.9 \%$. In the USA, it was said around $2 \%$ to $5 \%$ and 16 million patients underwent surgery procedure each year and suffered from post-operation infection ${ }^{14}$.

NHS hospital in England mentioned the risk factors of SSI were age, sex, surgery duration and wound class, ASA score (pre-surgery physical status) which is under $93 \%$ and overall body mass index (42\%). SSI risks were varied based on the possibility of microbe contamination to the surgery. Colon surgery was the highest possibility $(10 \%)$, and the lowest was prosthesis surgery (1\%). NHS hospitals (2014) noted that based on its surveillance data in 2013-2014, the highest SSI was in orthopedic surgery. This might serve as the foundation for classifying the type of operation in the hospital for SSI surveillance data report ${ }^{15}$. 


\section{Risk evaluation and follow up}

The follow up from SSI risks which were analyzed from this research result is elaborated as follow:

\section{Lack of health workers hand washing compliance}

A hospital may manage the risks by socializing and educating the health workers to perform hand wash before and after surgery or during surgery wound care. Regular evaluation and audit of hand washing compliance can also be implemented. Based on the research by Pratama et al., the solution to increase handwashing compliance was by improving the knowledge through spreading out the evidence of hand hygiene effectiveness in reducing the numbers of bacteria through gel inspection ${ }^{16}$.

Mathur explained that in a clinical condition it was described as following when the health worker's hand did not appear dirty, alcohol-based hand rub could be applied regularly to decontaminate the hands. (a) before touching the patient. (b) before using sterile gloves for an intravascular catheter. (c) before inserting a urinary catheter, peripheral vascular catheter, or other invasive actions which do not require surgical procedures. (d) after touching the patient (such as measuring pulse or blood pressure, or lifting the patient). (e) after any contact with body fluid or excretion, mucous membrane, non-intact skin, and wound dressing if the hands did not appear dirty. (f) after touching inanimate medical objects (including tools) and contacting the patient surrounding. (g) after taking off the gloves. (h) When moving from a contaminated body to non-contaminated body during patient service. Surveillance and monitoring related to the implementation of hand hygiene compliance and five moments of infection prevention and control are needed ${ }^{17}$.

The culture of awareness toward infection risks has to be implemented to each health workers and health service workers in the hospital. Improving the motivation to maintain hand hygiene should be a rooted culture in the hospital. Sterile tools and workers who work aseptically such as sterile instruments both in surgery and inpatient rooms, handwashing, the use of the glove, and the use of masker are essential to prevent and control nosocomial infection such as surgical site infection. In a research conducted by Nurkusuma, it is also mentioned that the bandage dressing procedure without washing hand is contributory to MRSA event ${ }^{18}$.

Based on Chassin, Mayer, et al, the solution in relation to pressure in safety culture to maintain hand hygiene in all levels was by making hand hygiene as habit, assuring the head commitment for hand washing compliance to reach $\pm 90 \%$, serving as a role model by practicing proper hand hygiene, creating responsibility to all health workers such as doctors, nurses, food service staff, janitors, ecclesiastics, technicians, and therapists. Maintaining hand hygiene is a necessary action to cut infection transmission chain ${ }^{19}$.

\section{A minimum implementation of surgery wound control}

Report on SSI surveillance in the interview mentioned that the data and result were still bias. It was due to the lack of surgery wound control identification. Categorization, classification, and surgery type were not conducted during data collection. Research by Fatimah found that there was a significant relationship between surgery classifications with surgery site infection ${ }^{20}$.

The implementation of SSI surveillance still needed supervision and monitoring as well as socialization to IPCLN regarding the health worker knowledge to the symptoms of infection, data collection, completeness, and precision. Hospital had implemented SIMRS for HAIs surveillance report yet monitoring, and supervision related to the collected report filling and integrity of HAIs data was still needed. Based on research by Lowman, proactive surveillance significantly contributed to the reactive prevention of infection and was successfully reduce infection ${ }^{21}$. 
Research by Aisyah, et al. found out that there was a lack of data collection, precision, and form filling completeness. The implementation of data collection in Hospital X Surabaya was data correction reported by IPCLN. The variables that often left blank were: (a) cohort register that is the variables of surgery procedure, similar incision multi-procedure, ASA score, and wound clarification. (b) presurgery that is the variables of patient's temperature, smoking status, MRSA screening, steroid consumption, prior radiotherapy, bathe before surgery, and prophylactic. (c) during operation that was air circulation, air pressure, temperature, air count, AC fungi, surgery room humidity, additional antibiotic, and the numbers of staff ${ }^{6}$.

\section{Lack of management support}

Cooperation and involvement of the management in preventing and controlling hospital infection is necessary. The role of the director in preventing and controlling infection should serve as connecting media between managers and health workers through performance monitoring and support ${ }^{22}$.

Research conducted by Mustariningrum, et al. mentioned that supervision from the top level will increase the efficiency and reduce errors in working. Based on the research analysis, the role of head and cooperation in SSI discussion was still minimum. The collaboration among PPI team in the surgery room was also not as expected. This should trigger any improvements ${ }^{23}$.

The level of managerial strategy was to ensure actions in controlling the effectiveness of infection control implemented in infection control. More importantly, there was support from the management and board of directors of the hospital. Nosocomial infection prevention became all individual and health service worker responsibility ${ }^{22}$.

According to Darmadi, the first method was by increasing the host resistance through active or passive immunization through health promotion. The second method was to exterminate or inactivate the infectious agent through a physical process such as heating (pasteurization or sterilization) and by cooking the food as needed as well as through chemical processes such as water chlorination and disinfection. The third method was to cut the transmission chain. The latest action was the most natural method, but the result was dependent on the worker compliance in implementing the stated procedures. This preventive actions had been specified in isolation precaution which consisted of standard precaution and transmission-based precaution. The fourth was preventive action after exposure such as transmission via blood and other body fluid due to used needlestick or other exposure ${ }^{2}$.

Based on the regulation from The Health Department (2011), the center of infection elimination was through correct hand hygiene. The most important aspect that a hospital has to concern in target $\mathrm{V}$ of patient safety and the implementation of infection risks reduction related to health service that is:

i. Hospital adopts or adapts the most updated guidance of hand hygiene published and commonly used (such as from WHO Patient Safety).

ii. Hospital implements effective hand hygiene program.

iii. Develop policies or procedures to guide the sustainable risk reduction against the infection related to health service ${ }^{24}$.

Based on WHO Global Strategy, the right consumption of antibiotic was an adequate consumption of medicines regarding cost and the increase of clinical therapeutic effect, to minimize drug toxicity, and to minimize possible resistance ${ }^{25}$. Amin mentioned that the success of antibiotic drugs was influenced by several aspects that are the type of antibiotic, antimicrobial spectrum, pharmacologic aspect, germ micrology aspect, patient aspect, and the pattern of antimicrobial treatment ${ }^{26}$. A re-surveillance is required about the consumption of prophylactic antibiotic during surgery such as the pattern of antibiotic use, appropriateness of standard antibiotic therapy and rationality of antibiotic consumption covering accurate indication, right drug, precise dosage, precise patient, drug side effect precaution, drug interaction precaution in Hospital. 
Bratzler et al. described the consumption of prophylactic antibiotic before the surgery aimed to control the infection control to prevent any post-surgery risks. The time management to give the medicine before the operation was 60 minutes before surgical incision which was a particular time as recommended in the induction of anesthesia. There were agents such as vancomycin and fluoroquinolones, which needed 1-2 hours; therefore, the antibiotic was given 120 minutes before the surgical incision. There was a new recommendation for prophylactic for a post-surgery program that was to shorten the antimicrobial by involving single dose or the following dosage that was given less than 24 hours $^{27}$.

The hospital staff needs the training to improve their knowledge. The aims of this education and training, according to Moekijat are: (1) to develop the skill to accomplish the work faster and more efficient, (2) to improve the knowledge in order to achieve the work rationally, (3) to develop attitude so that the willingness among the workers and management to work together. The training program from Infection control was expected to reinvigorate the knowledge, to improve it, to increase the motivation, and to improve staff work performance ${ }^{28}$.

The strategy to decrease HAIs based on the agreement was to conduct training on service of Infection Prevention and Control (IPC), hand hygiene facility procurement such as sink and hand rub, material development for education and leaflet related to hand hygiene in serving the infection prevention and control, optimize HAIs surveillance activities, conduct regular HAIs meeting to discuss HAIs-related issues, report, cooperation, evaluation, socialization and monitoring related to HAIs and its prevention, SOP refreshment for the types of HAIs such as:

i. SSI with SOP reinvigoration of pre-surgery, during surgery, and post-surgery management. SSI surveillance SOP

ii. UTI (urinary infection) with SOP reinvigoration on catheter urinary insertion, care, and release. ISK surveillance SOP

iii. VAP with SOP reinvigoration on ventilator installation and maintenance. VAP surveillance SOP

iv. BSI with SOP reinvigoration on preparation and central intravenous insertion. BSI surveillance SOP

v. Phlebitis with SOP reinvigoration on infusion insertion and care

vi. Decubitus with SOP reinvigoration on decubitus care guidance

Below is the recommendation of strategies to reduce HAIs which can be implemented by the hospital based on the period of strategy implementation:

\section{Long-term}

About the rational consumption of antibiotic since this issue needs approach, attitude change, and continuous staff training are required. Identification of bacteria causing HAIs to enable the hospital to prepare the tools and laboratory completeness to conduct bacterial culture is also needed.

\section{Midterm}

The implementation of infection prevention and control by monitoring, socializing and evaluating continuously with the staff. Next, is to improve the cooperation and support from the management to ensure that the implementation runs maximally.

\section{Long-term}

To cut the chain of infection transmission through hand washing compliance, the use of APD, and sterile medical tools by increasing each staff awareness and changing their attitude. This strategy can be conducted within a short-term plan because hand washing is a simple activity and to improve this 
habit is by reinforcing each awareness. Continuous training for the staff to enhance their knowledge concerning infection prevention and control is needed.

\section{Conclusion}

Based on the research result in Infection Control Risk Assessment analysis and strategies to decrease Health-Care Associated Infection in Hospital Yogyakarta, it can be concluded as follow:

HAIs identification in Hospital showed that the risks found and analyzed were (1) the transmission of infectious disease through direct and indirect contact, (2) transmission, entry, and the growth of microorganism, (3) virus/bacteria entry in the air (respiratory disorders TB, influenza), (4) infection (SSI, VAP, UTI, BSI, phlebitis, and decubitus), (5) length of care, delay of homecoming, disability, and even death. These risks of infection might affect the health workers, patients, visitors, and ward area or the environment of the hospital.

Based on the HAIs risks and assessment, it was found out the highest risk for HAIs was SSI. The evaluation of HAIs risk was the health workers' non-compliance of handwashing, minimum control implementation on surgery wound, and less support from management. The follow up of SSI was immediate action, concern from the director of the hospital, in-depth analysis, SPO audit and hand hygiene compliance, patient refreshment during surgery and conduct socialization of SSI surveillance, and in detail surgery site identification and control. The strategy to reduce SSI infection in Hospital Yogyakarta was by cutting the infection transmission (through maintaining hand sanitation, using PPE, keeping tools medical sterilization), by identifying bacteria causing SSI, using rational antibiotic, optimizing HAIs surveillance activities, conducting regular meeting to discuss SSI-related issues, report, cooperation, evaluation, SSI socialization and monitoring as well as its prevention, SPO refreshment, and SSI management.

\section{References}

Aisyah, Z \& Satyabakti, P. (2013). Surveilans Infeksi Daerah Operasi (IDO) menurut Komponen Surveilans di Rumah Sakit X Surabaya tahun 2012. Departemen Epidemiologi Fakulatas Kesehatan Masyarakat Universitas Airlangga, Surabaya Jawa Timur. Jurnal berkala epidemilogi, Vol 1 , no. 2 September 2013: 254-265.

Amin, L.Z (2014). Pemilihan antibioik yang raisional. Vol 27. Accessed on 18 August 2016 retrieved from

http://cme.medicinus.co/file.php/1/MEDICAL_REVIEW_Pemilihan_Antibiotik_yang_Rasional .pdf

Astuti, Murwani E. (2010). Identifikasi dan Implementasi Manajemen Risiko di Rumah Sakit Umum Banyumas. Tesis. Fakultas Ekonomika dan Bisnis Universitas Gajah Mada

Brannigan E, Murray E, Holmes A. (2009). Where does infection control fit into a hospital management structure?. J Hosp Infect 73(4):392e6.

Bratzler, DQ., et al. (2013). Clinical Practice Guidelines for Antimicrobial Prohylaxis in Surgery. American Journal of Helath System Pharmacy. Februari 2013. http://www.ajhp.org/content/70/3/195.long?sso-checked=true

Chassin, M.R., Mayer, C., Nether, K (2015). Improving Hand Hygiene at Eight Hospital in The United States by Targeting Specific Causes of Noncompliance. The Jpint Commission Journal on Quality and Patient Safety. Volume 41st. http://www.jointcommissionjournal.com/article/S1553-7250(15)41002-5/abstract

Darmadi (2008). Infeksi Nosokomial : Problematika dan Pengendaliannya, Salemba Medika.

Departemen Kesehatan (2007). Profil Kesehatan 2007. Departemen Kesehatan RI.

Ernawati, E., Tri. A.R., Wiyanto. S. (2014).Penerapan Hand hygiene Perawat di Ruang Rawat Inap Rumah Sakit. Jurnal Kedokteran Brawijaya. Accessed on 1 Agustus 2016 retrieved from Http://kb.ub.ac.id /idex.php /jkb/artcle/ view.file/523/409. 
Fatimah, S., (2011). Faktor-faktor yang Berhubungan dengan Terjadinya Infeksi Nosokomial Luka Operasi di Ruang di RSUP Fatmawati Tahun 2011. Jakarta: Universitas Pembangunan Nasional Veteran.

International Organization for Standardization. (2009). ISO 31000 Risk Management. https://www.iso.org/iso-31000-risk-management.html

Kadi, A.A and Salati, S.A.(2012). Hand Hygiene Practices among Medical Students. Accessed on 25 January2016http://www.bmj.com/search/Hand\%20Hygiene\%20Practices\%20among\%20Medic al\%20Students?page $=6$

Kementerian Kesehatan. (2010). Petunjuk Praktis Surveilans Infeksi Rumah Sakit.Jakarta: Kementerian Kesehatan RI.

Lardo S., Prasetyo B., Purwaamidjaja D.B. (2016). Infection Control Risk Assessment (ICRA). CDK238 Vol 43 no. 3 the 2016. Accessed on 4 March 2016 retrieved from http://www.kalbemed.com/Portals/6/19 238AnalisisInfection\%20Control\%20Risk\%20Assessment-ICRA.pdf

Lowman, W. (2016). Active surveillance of hospital-acquired infections in South Africa: Implementation, impact and challenges. SAMJ research vol. 106, No. 5. Accessed on 31 August 2016, retrieved from http://www.samj.org.za/index.php/samj/article/view/10783/7312

Mathur, P. (2011). Hand hygiene: Back to the basics of infection control. IndianJournal Medical Research.2011 Nov; 134(5): 611-620. Accessed on 7 August 2016 retrieved from http://www.ncbi.nlm.nih.gov/pmc/articles/PMC3249958/?report=classic

Mawalla, Brian et al. (2011). Predictors of surgical site infections among patients undergoing major surgery at Bugando Medical Centre in Northwestern Tanzania. BMC Surgery 11:21.

Moekijat, 2003. Latihan dan Pengembangan Sumber Daya Manusia. PT Mandiri Maju. Bandung.

Muninjaya (2004). Manajemen Kesehatan. Jakarta, Penerbit Buku Kedokteran, EGC

Mustariningrum, D.L., Koeswo, M., Ahsan. (2015). Kinerja IPCLN dalam pencegahan dan pengendalian Infeksi di Rumah Sakit: peran pelatihan, motivasi kerja dan Supervisi. Universitas Brawijaya Malang. Accessed on 30 August 2016 retrieved from http://jurnaljam.ub.ac.id/index.php/jam/article/viewFile/814/763

National Health and Medical Research Council. (2010). Australian Guidelines for the Prevention and Control of Infection in Healthcare, HEALTHCARE ASSOCIATED INFECTION RISK MANAGEMENT AND PATIENT SAFETY STANDARDS: Categorised guidance on recommended practice and legal and professional standards in Infection Control. Australian government. NHMRC-ICG Project Team, Canberra. Accessed on 5 January 2016 retrieved from

http://www.nhmrc.gov.au/ files nhmrc/publications/attachments/cd33 infection control health care.pdf

NHS Hospital, 2012. Surveillance of Surgical Site Infection in NHS Hospital in England. https://www.gov.uk/government/uploads/system/uploads/attachment_data/file/364326/SSI_ann ual_report England 2011_12.pdf

Nurkusuma, D.D. (2009). Faktor yang berpengaruh terhadap kejadian Methicillin-Resistant Straphylococcuss aureus (MRSA) pada kasus infeksi luka pasca operasi di ruang perawatan bedah Rumah Sakit Dokter Kariadi Semarang. Program Pasca Sarjana Magister Ilmu Biomedik. Tesis terpublikasi. Accessed on 31 Augustus 2016 retrieved from https://core.ac.uk/download/files/379/11728168.pdf

Pratama, B.S., Koeswo, M., Rokhmad, K (2015). Faktor Determinan Kepatuhan Pelaksanaan Hand Hygiene pada Perawat IGD RSUD dr. Iskak Tulungagung. Volume 28. http://jkb.ub.ac.id/index.php/jkb/article/view/954

Weston, M, and Robert, D (2013). The Influence of Quality Improvement Effort on Patient Outcomes and Nursing Work: A Perspective from Chief Nursing Officers at Three Large Health Systems. The Online Journal of Issues in Nursing, Volume 8th. http://www.nursingworld.org/qualityimprovement-on-patient-outcomes.html

World Health Organization (2009). WHO Guidelines on Hand Hygiene in Health Care. First Global Patient Safety Challenge Clean Care is Safer Care. http://apps.who.int/iris/bitstream/10665/44102/1/9789241597906 eng.pdf

World Health Organization (WHO). (2011). HAIs Surveillance. Accessed on 23 January 2016 retrieved from http://www.who.int/bulletin/volumes/89/10/11-088179/en/ 
World Health Organization. (2014). Antibiotik resistence: synthesis of recommendetion by expert policy group Allince for Prudent Use of antibiotic. 